\title{
A New Mass Screening Method of Detecting UDP-Galactose-4-Epimerase Deficiency
}

\author{
Yushin Fujimura, Masahiko Kawamura* and Hiroshi \\ NARUSE ${ }^{\dagger}$ \\ Department of Microbiology, Nagoya City Public Health In- \\ stitute, Nagoya 467, *Clinic of Pediatrics, Meijo Hospital, \\ Nagoya 460, and $\dagger$ National Center for Nervous, Mental and \\ Muscular Diseases, Kodaira 187
}

\begin{abstract}
Fujimura, Y., Kawamura, M. and Naruse, H. A New Mass Screening Method of Detecting UDP-Galactose-4-Epimerase Deficiency. Tohoku J. exp. Med., 1980, 131 (1), 15-22 — A new mass sreening method for detecting UDP-galactose-4-epimerase deficiency in newborn infants was devised so as to make a useful addition to the Guthrie test. Like Beutler's method, this method enables one to perform convenient spot tests on the basis of fluorometry of NADH. The preferred procedure was determined to be as follows: To a mixture of $10 \mu \mathrm{l}$ of 5-10 mM UDP-galactose, $10 \mu \mathrm{l}$ of $26 \mathrm{mM} \mathrm{NAD,} 10 \mu \mathrm{l}$ of a $1 \mathrm{M}$ tris-HCl buffer (pH 8.0) and $10 \mu \mathrm{l}$ of a $1 / 100$ dilution of a $5 \mathrm{mg} / \mathrm{ml}$ UDP-glucose dehydrogenase stock solution, distilled water is added until the total volume reaches $100 \mu \mathrm{l}$. Then a blood-bearing filter paper dise is added to the mixture and, the reaction mixture is incubated at $37^{\circ} \mathrm{C}$ for $6-17 \mathrm{hr}$. The resulting test solution is spotted on a Whatman No. 1 filter paper with a capillary tube, air-dried and tested for fluorescence with an ultraviolet light detector. No cases of UDP-galactose4-epimerase deficiency were found in the present study. U_ UDP-galactose4-epimerase; mass screening spot test
\end{abstract}

UDP-galactose-4-epimerase (EC. 5. 1. 3. 2) (abbreviated as EPase), which was discovered by Leloir (1951), not only functions as the third enzyme participating in the metabolism of galactose (abbreviated as Gal), but also serves in the synthesis of Gal from glucose in the reversed reaction when galactose is necessary to the living body.

In 1971, Gitzelmann (1972) first discovered the newborn infant with EPase deficiency. Since then, Gitzelmann and associates reported a total of 7 patients with EPase deficiency including 3 newborn infants discovered among those showing elevated blood levels of galactose-1-phosphate (abbreviated as Gal-1-P) which were detected through mass screening; one girl was the sister of one of the infants, and 3

Received for publication, January 9, 1979.

Reprint requests: Masahiko Kawamura, M.D., Clinic of Pediatrics, Meijo Hospital, 1-3-1 Sannomaru, Naka-Ku, Nagoya 460. 
women aged 60 years or more (Gitzelmann and Steinmann 1973; Mitchell et al. 1975; Gitzelmann et al. 1976). Conventionally, EPase activity is determined by using a considerable amount of blood and measuring the absorbance of NADH at $340 \mathrm{~nm}$ in the deproteinized sample. However, this procedure is not suitable for mass screening. We have devised a new mass screening method for detecting EPase deficiency in newborn infants which, like Beutler's method (Beutler and Baluda 1966), enables one to perform convenient spot test. This paper is a report on the preferred reaction system for our new method.

\section{Materials and Methods}

Principle. EPase converts UDP-galactose (abbreviated as UDP-Gal) to UDP-glucose which, in the presence of UDP-glucose dehydrogenase (abbreviated as UDPGDHase), reacts with NAD to form UDP-glucuronate and NADH. The resulting NADH is fluorometrically determined with an ultraviolet light detector.

Reagents. UDP-Gal (Sigma, Boehringer), NAD, NADH, UDPGDHase (Boehringer). $1 \mathrm{M}$ tris-HCl buffer ( $\mathrm{pH} 8.0$ ), $1 \mathrm{M}$ glycine buffer ( $\mathrm{pH} 8.7$ ), $0.35 \mathrm{M}$ phosphate buffer (pH 8.0), 0.2 M veronal buffer ( $\mathrm{pH} 8.0$ ), $1 \mathrm{M}$ triethanolamine buffer ( $\mathrm{pH} 8.0$ ), $0.2 \mathrm{M}$ collidine buffer ( $\mathrm{pH} 8.0$ ), $0.2 \mathrm{M}$ borate buffer ( $\mathrm{pH} \mathrm{8.0)}$ ).

Specimens. Blood specimens were those obtained from newborn infants and sent to us for Guthrie testing, namely, from subjects in whom abnormalities were detected by Paigen's method (Personal communciation; Ishii and Tago 1976), Fujimura's method (1977a, b, c) or Beutler's method (1966).

Reaction systems. System $1(40 \mu \mathrm{l})$ : To a mixture of $10 \mu \mathrm{l}$ of $10 \mathrm{mM}$ UDPGal, $10 \mu \mathrm{l}$ of $13 \mathrm{mM} \mathrm{NAD}, 10 \mu \mathrm{l}$ of a $1 \mathrm{M}$ glycine buffer $(\mathrm{pH} 8.7$ ) and $10 \mu \mathrm{l}$ of a 1/100 dilution of a 5 $\mathrm{mg} / \mathrm{ml}$ UDPGDHase stock solution was added a blood-bearing filter paper disc with a diameter of $3 \mathrm{~mm}$. By replacing each one of the components with distilled water, four control systems were prepared, namely, UDPGal-free, NAD-free, enzyme-free and disc-free systems. The reaction was carried out in tightly stoppered small test tubes or a covered tray for use in TPHA. After incubation at $37^{\circ} \mathrm{C}$ for $3-6 \mathrm{hr}$ the test solution was treated according to either of the following procedures.

Procedure $A$. The test solution was spotted on a Whatman No. 1 filter paper with a capillary tube and air-dried. Then, its fluorescence intensity at $356 \mathrm{~nm}$ was measured with an ultraviolet light detector (Super Light SL-DI) by comparison with fluorescence standards prepared by mixing NADH and NAD in various proportions according to the previous reports (Fujimura et al. 1977a, b, c). When the concentration of hemoglobin was too high, the following alternative procedure was employed.

Procedure $B$. The test solution was sucked into a capillary tube and its tip was sealed with putty for use in hematocrit determination. Proteins were denatured by heating the capillary in boiling water for $2 \mathrm{~min}$. Then the sealed tip was cut away and the content of the capillary tube was spotted on a Whatman No. 1 filter paper. This procedure eliminates the adverse effect of hemoglobin and permits a clear-cut determination.

System II $(100 \mu \mathrm{l})$ : To a mixture of $10 \mu \mathrm{l}$ of $10 \mathrm{mM}$ UDPGal, $10-20 \mu \mathrm{l}$ of $13 \mathrm{mM}$ $\mathrm{NAD}, 10 \mu \mathrm{l}$ of a $1 \mathrm{M}$ tris-HCl buffer $(\mathrm{pH} 8.0$ ) and $10 \mu \mathrm{l}$ of a $1 / 20-1 / 200$ dilution of a $5 \mathrm{mg} /$ ml UDPGDHase stock solution, distilled water was added to a total volume of $100 \mu \mathrm{l}$. To this mixture was added a blood-bearing filter paper disc of $3 \mathrm{~mm}$ diameter and the reaction mixture was incubated at $37^{\circ} \mathrm{C}$ for 6 or $17 \mathrm{hr}$. The control systems and the subsequent procedures were the same as described for system I. When system II was used, the concentration of hemoglobin was so low that fluorometric determination was possible without resorting to the above-mentioned heat treatment. 


\section{REsults}

\section{Relationship between concentration and activity of UDPGDHase}

Using systems I $(40 \mu \mathrm{l})$ and II $(100 \mu \mathrm{l})$, the relationship between concentration and activity of UDPGDHase was studied. A glycine buffer ( $\mathrm{pH} 8.7$ ) was used for system I and a tris- $\mathrm{HCl}$ buffer for system II. As shown in Table 1, when system I was employed, a maximum fluorescence intensity was attained with $10 \mu \mathrm{l}$ of a $1 / 50$ or $1 / 100$ dilution of $5 \mathrm{mg} / \mathrm{ml}$ UDPGDHase stock solution (a final concentration, $5 \mathrm{mg} / \mathrm{ml} \times 1 / 200$ or $1 / 400$ ). The fluorescence intensity decreased at higher concentrations. This may be due to inhibitory effect of excess $\mathrm{NH}_{4}+$ ions. In this system, the hemoglobin concentration was so high that often the fluorometric determination was interferred. In such cases, the application of Procedure B was useful. None of the control systems produced fluorescence and were rated as fluorescencenegative, except the UDPGal-free system which occasionally fluoresced slightly possibly due to contamination with the endogenous UDPGal or other dehydrogenases present in the blood specimen. System II was more convenient because there was negligible interference with the fluorometric determination by the presence of hemoglobin and could be achieved according to Procedure A, namely, without any heat treatment. When this system was employed, it took 6-17 hr to attain a maximum fluorescence intensity. When the incubation time was $2 \mathrm{hr}$, no fluorescence was produced below $1 / 50$ dilution of the $5 \mathrm{mg} / \mathrm{ml}$ UDPGDHase stock solution. However, when the incubation time was $6-17 \mathrm{hr}$, a maximum fluorescence intensity was attained even at a dilution of $1 / 200$ (a final concentration, $5 \mathrm{mg} / \mathrm{ml} \times 1 / 2000$ ). All control systems were rated as fluorescence-negative.

TABLE 1. Relationship between concentration and activity of UDPGDHase

System I

\begin{tabular}{ccccccccc}
\hline & \multicolumn{8}{c}{ UDPGDHase concentration* } \\
\cline { 2 - 7 } & $\times 1 / 2$ & $\times 1 / 10$ & $\times 1 / 20$ & $\times 1 / 50$ & $\times 1 / 100 \times 1 / 200 \times 1 / 500 \times 1 / 1000$ \\
\hline Procedure A & - & +1 & +1 & +3 & +3 & +2 & \pm & \pm \\
B & \pm & +1 & +2 & +4 & +4 & +3 & +1 & \pm \\
\hline
\end{tabular}

Incubation: $37^{\circ} \mathrm{C}, 3 \mathrm{hr}$. Buffer: glycine.

System II

\begin{tabular}{|c|c|c|c|c|c|c|c|c|}
\hline & \multirow{2}{*}{$\begin{array}{l}\text { Time of } \\
\text { incubation } \\
\text { at } 37^{\circ} \mathrm{C}\end{array}$} & \multicolumn{7}{|c|}{ UDPGDHase concentration* } \\
\hline & & $\times 1 / 2$ & $\times 1 / 10$ & $\times 1 / 20$ & $\times 1 / 30$ & $\times 1 / 50$ & $\times 1 / 100$ & $\times 1 / 200$ \\
\hline \multirow{5}{*}{ Procedure A } & $30 \mathrm{~min}$ & $一$ & - & 一 & - & - & 一 & - \\
\hline & $2 \mathrm{hr}$ & +1 & +2 & +2 & +2 & +1 & - & - \\
\hline & $4 \mathrm{hr}$ & +2 & +2 & +3 & +2 & +2 & +1 & - \\
\hline & $6 \mathrm{hr}$ & +4 & +4 & +4 & +4 & +4 & +4 & +4 \\
\hline & Overnight & +4 & +5 & +5 & +5 & +5 & +5 & +5 \\
\hline
\end{tabular}

Buffer: tris-HCl.

* A $5 \mathrm{mg} / \mathrm{ml}$ UDPGDHase stock solution was diluted in the indicated proportions and $10 \mu \mathrm{l}$ of each dilution was used. 


\section{Effect of UDPGal and NAD concentration on EPase activity}

Ten $\mu$ l of $5 \mathrm{mM}$ UDPGal (a final concentration of $1+1 / 4 \mathrm{mM}$ ) was sufficient for system I to attain a maximum fluorescence intensity. For system II, $10 \mu \mathrm{l}$ of 5 mM UDPGal (a final concentration of $1 / 2 \mathrm{mM}$ ) was sufficient. With respect to $\mathrm{NAD}$, at least $10 \mu \mathrm{l}$ of $13 \mathrm{mM}$ NAD (a final concentration of $3+1 / 4 \mathrm{mM}$ ) was required for system I to attain a maximum fluorescence intensity, and for system II, at least $10 \mu \mathrm{l}$ of $26 \mathrm{mM} \mathrm{NAD}$ (a final concentration of $2+3 / 5 \mathrm{mM}$ ).

\section{Time course of fuorescence intensity during incubation}

As can be seen in Table 1, it took 6-17 hr to attain a maximum fluorescence intensity. In system I, it also took $17 \mathrm{hr}$ to attain a maximum fluorescence intensity (Table 2). All control systems were rated as fluorescence-negative.

\section{Effect of buffer type on EPase activity}

Various types of buffers, such as tris-HCl, glycine, phosphate, veronal, triethanolamine, collidine and borate buffers, were tested in system II. As shown in Table 3, the most suitable was tris- $\mathrm{HCl}$ buffer and this was followed by triethanolamine, glycine, and phosphate buffers in that order. Veronal, collidine and borate buffers were unsuitable. All control systems were rated as fluorescencenegative. From the above-mentioned results, we have concluded that system II is

TABLE 2, Time course of fluorescence intensity during incubation

System I*

\begin{tabular}{|c|c|c|c|c|c|c|c|}
\hline & & \multicolumn{6}{|c|}{ Time $(\mathrm{hr})$ of incubation at $37^{\circ} \mathrm{C}$} \\
\hline & & 0.5 & 1 & 2 & 4 & 6 & 17 \\
\hline Procedure & A & +1 & +1 & +2 & +2 & +3 & +5 \\
\hline & B & +2 & +3 & +3 & +4 & +4 & +6 \\
\hline
\end{tabular}

* This system consisted of $10 \mu \mathrm{l}$ of $10 \mathrm{mM}$ UDPGal, $10 \mu \mathrm{l}$ of $13 \mathrm{mM}$ NAD, $10 \mu \mathrm{l}$ of a $1 \mathrm{M}$ glycine buffer $(\mathrm{pH} 8.7)$ and $10 \mu \mathrm{l}$ of a $1 / 100$ dilution of $5 \mathrm{mg} / \mathrm{ml}$ UDPGDHase stock solution.

TABLE 3. Effect of buffer type on EPase activity

System II*

\begin{tabular}{|c|c|c|c|c|c|c|c|c|}
\hline & \multirow{2}{*}{$\begin{array}{c}\text { Time of } \\
\text { incubation } \\
\text { at } 37^{\circ} \mathrm{C}\end{array}$} & \multicolumn{7}{|c|}{ Buffers } \\
\hline & & Tris-HC & I Glycine & Phosphate & Veronal & $\begin{array}{l}\text { Triethanol- } \\
\text { amine }\end{array}$ & Collidine & Borate \\
\hline \multirow{5}{*}{ Procedure A } & $1 \mathrm{hr}$ & +1 & - & - & - & +1 & 一 & - \\
\hline & $2 \mathrm{hr}$ & +1 & - & - & $\cdots$ & +1 & - & 一 \\
\hline & $4 \mathrm{hr}$ & +2 & +1 & +1 & - & +2 & - & - \\
\hline & $6 \mathrm{hr}$ & +4 & +3 & +2 & - & +3 & - & - \\
\hline & $17 \mathrm{hr}$ & +5 & +4 & +3 & - & +4 & - & +1 \\
\hline
\end{tabular}

* This system consisted of $10 \mu \mathrm{l}$ of $10 \mathrm{mM}$ UDPGal, $10 \mu \mathrm{l}$ of $26 \mathrm{mM} \mathrm{NAD,} 10 \mu 1$ of a buffer, $10 \mu \mathrm{l}$ of a $1 / 20$ dilution of $5 \mathrm{mg} / \mathrm{ml}$ UDPGDHase stock solution and $60 \mu \mathrm{l}$ of water. 
the most suitable for our mass screening method. The preferred procedure is as follows: To a mixture of $10 \mu \mathrm{l}$ of 5-10 mM UDPGal, $20 \mu \mathrm{l}$ of $13 \mathrm{mM} \mathrm{NAD,} 10 \mu \mathrm{l}$ of a $1 \mathrm{M}$ tris-HCl buffer and $10 \mu \mathrm{l}$ of a $1 / 100$ dilution of a $5 \mathrm{mg} / \mathrm{ml}$ UDPGDHase stock solution, distilled water is added to a total volume of $100 \mu \mathrm{l}$. Then a bloodbearing filter paper disc of $3-\mathrm{mm}$ diameter is added and the reaction mixture is incubated at $37^{\circ} \mathrm{C}$ for hours or overnight.

EPase activities in patients discovered by Paigen's, Fujimura's and Beutler's methods

Our method was employed to determine EPase activity in 30 patients whose reaction had been detected by Guthrie testing of approximately 30,000 newborn infants (Table 4). They showed abnormally high values when tested by Paigen's method; abnormally high Gal-1-P and galactose (abbreviated as Gal) values when tested by Fujimura's method; or galactosemia positive or false-positive results when tested by Beutler's method. The patients showing abnormally high Gal-1-P values were suspected to EPase deficiency, but no cases of EPase deficiency were found in the present study. However, a few patients showing lower EPase activities appeared to be heterozygotes. In Table 4, Patient 1 gave the following laboratory findings: higher than $20 \mathrm{mg} \%$ by Paigen's method; $24.4 \mathrm{mg} \%$ Gal and $6.4 \mathrm{mg} \%$ Gal-1-P by Fujimura's method; and normal by Beutler's method. This patient was initially suspected of galactokinase deficiency, but the activity of EPase was found to be normal. Patients 2 and 3 , who were the parents of patient 1 , were suspected of cataract. It is of interest that, although their laboratory finding were approximately $0 \mathrm{mg} \%$ Gal and Gal-1-P by Fujimura's method and normal by Beutler's method, the activity of EPase was slightly reduced in both. Patients 24 and 25 suffering from galactosemia were under medical treatment. Their Gal-1-P and Gal values were practically zero, but their EPase activities were lower than those of the remaining patients. Of the patients showing values of higher than 20 $\mathrm{mg} \%, 12-20 \mathrm{mg} \%, 8-12 \mathrm{m6} \%, 8 \mathrm{mg} \%, 6-8 \mathrm{mg} \%$ and $4-6 \mathrm{mg} \%$ by Paigen's method, the majority had normal EPase activities. However, patient 12 (8 $\mathrm{mg} \%$ by Paigen's method; $11.9 \mathrm{mg} \%$ Gal-1-P and $2.5 \mathrm{mg} \%$ Gal by Fujimura's method), patient 16 ( $6-8 \mathrm{mg} \%$ by Paigen's; normal by Beutler's), patient $22(4-6 \mathrm{mg} \%$ by Paigen's; $7.1 \mathrm{mg} \%$ Gal-1-P and $0.3 \mathrm{mg} \%$ Gal by Fujimura's; normal by Beulter's) and patient 26 (false-positive by Beutler's) may have been heterozygotes, judging from their low EPase activities.

\section{Discussion}

Previously it was thought that EPase deficiency could be detected solely by determining EPase activity in patients showing elevated blood levels of Gal-1-P detected through mass screening. We have now devised a new mass screening method which, like Beutler's method, enables one to perform convenient spot tests for EPase activity. When practically applied, our method gave satisfactory results.

Green and Ebner (1977) and Green et al. (1977) isolated EPase from bovine 
TABLE 4. EPase activities in patients discovered

\begin{tabular}{|c|c|c|c|c|c|}
\hline \multirow{2}{*}{ Patient No. } & \multirow{2}{*}{ Paigen's method } & \multicolumn{2}{|c|}{ Fujimura's method } & \multirow{2}{*}{$\begin{array}{l}\text { Beutler's } \\
\text { method* }\end{array}$} & \multirow{2}{*}{ EPase $†$} \\
\hline & & Gal-1-P & Gal & & \\
\hline & $(m g \%)$ & $(m g \%)$ & $(m g \%)$ & & \\
\hline 1 & $>20$ & 6.4 & 24.4 & $\mathbf{N}$ & +6 \\
\hline 2 & 0 & & & N & +3.5 \\
\hline 3 & 0 & & & $\mathrm{~N}$ & +3.5 \\
\hline 4 & $\geqq 20$ & & & $\mathbf{N}$ & +5 \\
\hline 5 & $12-20$ & & & $\mathbf{N}$ & +4 \\
\hline 6 & $12-20$ & & & $\mathbf{N}$ & +5 \\
\hline 7 & $8-12$ & & & $\mathrm{~N}$ & +6 \\
\hline 8 & $8-12$ & & & $\mathbf{N}$ & +6 \\
\hline 9 & 12 & & & N & +5 \\
\hline 10 & 10 & & & $\mathbf{N}$ & +5 \\
\hline 11 & 8 & & & N & +5 \\
\hline 12 & 8 & & & N & +4 \\
\hline 13 & 8 & 11.9 & 2.5 & $\mathbf{N}$ & +3 \\
\hline 14 & $6-8$ & & & $\mathbf{N}$ & +6 \\
\hline 15 & $6-8$ & & & $\mathrm{~N}$ & +4 \\
\hline
\end{tabular}

* The abbreviations are defined as follows: N, normal; G, galactosemia, f.p. false-

+ Fluorescence intensity below +1 indicates EPase deficiency, while those above

tissue and determined its activity according to two different procedures, a direct and an indirect one. In the direct procedure, a complete reaction system was prepared at the beginning and its absorbacne at $340 \mathrm{~nm}$ was measured after incubation. In the indirect one, a mixture of UDPGal, NAD, a buffer and EPase specimen were incubated at $24^{\circ} \mathrm{C}$ for 4-10 $\mathrm{min}$, then the reaction was stopped by heating. Then, UDPGDHase was added to the mixture and the reaction mixture was again incubated at $24^{\circ} \mathrm{C}$ for $30 \mathrm{~min}$ and its absorbance at $340 \mathrm{~nm}$ was measured. We also tried an indirect procedure, but the results obtained were similar to those obtained by the direct one. Accordingly, we preferred the direct procedure as its simpler operation was suitable for mass screening purposes. In our reaction system, the optimum final concentration of UDPGal was $0.5 \mathrm{mM}$ which agreed with the value proposed by Green and Ebner (1977). As for NAD, we chose a concentration of $2.6 \mathrm{mM}$ though Green and Ebner (1977) recommended a value of $1 \mathrm{mM}$. We also concluded that a tris- $\mathrm{HCl}$ buffer $(\mathrm{pH} \mathrm{8.0)}$ was the most suitable while a glycyl-glycine buffer was used by Green and Ebner (1977) and Green et al. (1977). Our method conveniently permits blood specimens to be sent from distant places by mail because only a filter paper disc of 3-mm diameter is required as the blood carrier for each subject.

Although our method is a qualitative one, this method may also be applied for quantitative determination of EPase activity by measuring the fluorescence intensity of the deproteinized incubation mixture with a fluorophotometer after an appropriate dilution with distilled water. In the present study, we applied our method to 30 patients with anomalies in galactose metabolism who had been discovered by mass screening of approximately 30,000 newobrn infants. As a result, no patient with EPase deficiency was found except for a few suspected 
by Paigen's, Fujimura's and Beutler's methods

\begin{tabular}{|c|c|c|c|c|c|}
\hline \multirow{2}{*}{ Patient No. } & \multirow{2}{*}{ Paigen's method } & \multicolumn{2}{|c|}{ Fujimura's method } & \multirow{2}{*}{$\begin{array}{l}\text { Beutler's } \\
\text { method* }\end{array}$} & \multirow{2}{*}{ EPase $\dagger$} \\
\hline & & Gal-1-P & Gal & & \\
\hline & $(m g \%)$ & $(m g \%)$ & $(m g \%)$ & & \\
\hline 16 & $6-8$ & & & $\mathbf{N}$ & +3 \\
\hline 17 & $6-8$ & & & $\mathbf{N}$ & +5 \\
\hline 18 & $6-8$ & & & $\mathbf{N}$ & +6 \\
\hline 19 & $6($ Met 12, Tyr $8-12)$ & & & $\mathbf{N}$ & +5 \\
\hline 20 & 6 & & & $\mathbf{N}$ & +5 \\
\hline 21 & 6 & & & $\mathbf{N}$ & +5 \\
\hline 22 & $4-6$ & 7.1 & 0.3 & N & +3 \\
\hline 23 & $4^{-6}$ & & & $\mathbf{N}$ & +5 \\
\hline 24 & 0 & 0 & 0 & G & +3 \\
\hline 25 & 0 & 0 & 0 & $\mathrm{G}$ & +3 \\
\hline 26 & $4>$ & & & f.p. & +3 \\
\hline 27 & $4>$ & & & f.p. & +4 \\
\hline 28 & $4>$ & & & f.p. & +4 \\
\hline 29 & $4>$ & & & f.p. & +6 \\
\hline 30 & $4>$ & & & f.p. & +6 \\
\hline
\end{tabular}

positive.

+4 indicate normal

heterozygotes. We expect that our method will find wide acceptance for mass screening purposes.

\section{References}

1) Beutler, E. \& Baluda, M.C. (1966) A simple spot screening test for galactosemia. J. Lab. clin. Med., 68, 137-141.

2) Fujimura, Y., Yonesawa, S., Sato, T. \& Kawamura, M. (1977a) Mass screening for inborn errors of metabolism. (II) Simple micro semi-quantitative method of galactose determination in blood and urine by fluorescence. Jap. J. Pediat., 30, 1521-1526 (Japanese).

3) Fujimura, Y., Yonesawa, S., Sato, T. \& Kawamura, M. (1977b) Mass screening for inborn errors of metabolism. (III) Simple micro semi-quantitative method of galactose determination in blood and urine by fluorescence, and its practical application to patients. Jap. J. Pediat., 30, 1527-1528. (Japanese)

4) Fujimura, Y., Kawamura, M. \& Naruse, H. (1977c) A new method of galactose estimation in blood for mass screening of galactosemia. Papers on Galactosemia, published by Boehringer-Mannheim-Yamanouchi Co. (Japanese)

5) Gitzelmann, R. (1972) Deficiency of uridine diphosphate galactose-4-epimerase in blood cells of an apparently healthy infant. Helv. paediat. Acta, 27, 125-130.

6) Gitzelmann, R. \& Steinmann, B. (1973) Uridine diphosphate galactose-4-epimerase deficiency. II. Clinical follow up biochemical studies and family investigation. Helv. paediat. Acta, 28, 497-510.

7) Gitzelmann, R., Steinmann, B., Mitchell, B. \& Haigis, E. (1976) Uridine diphosphate galactose-4-epimerase deficiency. IV. Report of eight cases in three families. Helv. paediat. Acta, 31, 441-452.

8) Green, C.R. \& Ebner, K.E. (1977) Purification and characterization of UDPgalactose-4-epimerase from bovine tissues. J. biol. Chem., 252, 2082-2088.

9) Green, C.R., Green, L.M. \& Ebner, K.E. (1977) Inhibition and inactivation of bovine mammary and liver UDP-galactose-4-epimerases. J. biol. Chem., 252, 2089-2094. 
10) Ishii, S. \& Tago, K. (1976) Mass screening for galactosemia using Paigen's method. Jap. J. clin. Path., 24, 1022-1024. (Japanese)

11) Leloir, L.F. (1951) The enzymatic transformation of uridine diphosphate glucose into a glactose derivatives. Arch. biochem. Biophys., 33, 186-190.

12) Mitchell, B., Haigis, E., Steinmann, B. \& Gitzelmann, R. (1975) Reversal of UDP-galactose-4-epimerase deficiency of human leukocytes in culture. Proc. nat. Acad. Sci. USA, 72, 5026-5030. 